\section{Bacteriological assessments of foodborne pathogens in poultry meat at different super shops in Dhaka, Bangladesh}

\author{
Jalal Uddin, ${ }^{1}$ Khaled Hossain, ${ }^{1}$ \\ Saddam Hossain, ${ }^{1}$ Karabi Saha, ${ }^{1}$ \\ Fatema Tuz Jubyda, ${ }^{1}$ Razoanul Haque, ${ }^{1}$ \\ Baki Billah, ${ }^{2}$ Ali Azam Talukder, ${ }^{1}$ \\ Anowar Khasru Parvez, ${ }^{1}$ \\ Shuvra Kanti Dey ${ }^{1}$ \\ ${ }^{1}$ Department of Microbiology and \\ ${ }^{2}$ Department of Zoology, Jahangirnagar \\ University, Dhaka, Bangladesh
}

\begin{abstract}
Poultry is now considered as a major fast-growing source of meat in the world. The consumers demand safe and hygienic products without contamination with pathogenic microorganisms when the production and consumption of poultry meat is gradually increasing. The present study was conducted to assess the bacterial contamination of dressed chicken collected from different supershops in Dhaka, Bangladesh. The chicken samples from $\mathrm{S}_{1}, \mathrm{~S}_{2}, \mathrm{M} 1, \mathrm{M}_{2}$ and $\mathrm{A}$ supershops were analyzed to determine the enteropathogenic bacteria in poultry meat. Three genera of bacteria were isolated from all of the chicken meat samples. These enteropathogens from various organs of dressing chickens were also enumerated. The isolates were presumptively identified as E. coli, Salmonella spp., and Shigella spp. by conventional culture method. The three enteropathogens were subjected to PCR assay for their confirmation as virulent enteropathogens. Only E. coli isolates were confirmed as pathogenic $E$. coli (Enterotoxigenic), other isolates were not confirmed as virulent Salmonella spp., Shigella spp.. Results of this study demonstrated that more cautions are recommended for personnel hygiene in processing and handling of poultry and poultry products to prevent occurrence of enterotoxigenic $E$. coli in dressed poultry meat sold by the supershops in Bangladesh.
\end{abstract}

\section{Introduction}

During 1980s, poultry industry was started as an excellent agribusiness in Bangladesh (Haque, 2001) and a tremendous development of this sector has been occurred since last decades (1996-2006) in the country (Rahman, 2003). In the mean- time, the sector has been a means of potential income generation and poverty alleviation, as well as improving human nutrition through the supply of meat and eggs to their daily life (BBS, 2008).

Though poultry meat and eggs provide nutritionally beneficial food containing protein of high quality, contamination of poultry meat and eggs can lead to food poisoning in humans through processing, handling, marketing and storage prior to cooking. The main causative agents of human intestinal infections from this source are bacteria, mainly Salmonella spp., E. coli, Staphylococcus spp. and Campylobacter spp. (FAO, 2013).

Escherichia coli is one of the common microbial flora that is found in the gastrointestinal tract of poultry and human being including other animals. It may become pathogenic to both poultry and human (Akond et al., 2009; Levine, 1987) although most isolates of $E$. coli are nonpathogenic. About 10 to $15 \%$ of intestinal coliforms are opportunistic, pathogenic serospecies (Akond et al., 2009) and responsible for a variety of lesions in immune-compromised hosts. They are associated with often severe diseases and sometimes with lethal infections such as meningitis, endocarditis, urinary tract infection, septicemia, epidemic diarrhea of adults and children (Akond et al., 2009). In addition, yolk sac infection, omphalitis, cellulitis, swollen head syndrome, coligranuloma, and colibacillosis are caused by Escherichia coli (Gross, 1994).

Poultry and poultry products are also an important reservoir of intestinal and foodborn pathogen like Salmonella. They are recognized as vital sources of Salmonella infection in human (Limawongpranee et al., 1999; Ocheni, 2015). Mostly, salmonellosis in human is caused by the consumption of contaminated poultry, pork, beef and eggs children (Akond et al., 2013).

According to the CDC Emerging Infections Program (CDC 2003), Shigella spp. was considered the third most reported food-borne bacterial pathogen in 2002 (Mokhtari et al., 2012) which are common especially with foods requiring processing or prepared by hand. These food-borne bacterial pathogens are found in foods when the foods are exposed to a limited heat treatment or served raw to the consumer (Wu et al., 2000). There is limited data on the prevalence of Shigella spp. amongst food handlers or on food products, though they cause shigellosis at high incident rate (Kapperud et al., 1995).

Generally, the people living in urban community of Bangladesh rely on the supershops for poultry meat. Alam et al.,
Correspondence: Shuvra Kanti Dey, Department of Microbiology, Jahangirnagar University, Savar, Dhaka-1342, Bangladesh. Tel./Fax: +88.01759588088 .

E-mail: shuvradey@yahoo.com

Key words: Poultry meat, Prevalence, Foodborne pathogens, Super Shop.

Acknowledgements: the auhtors would like to thanks all laboratory staffs, Department of Microbiology, Jahangirnagar University to provide kind support during this research work.

Contributions: the authors contributed equally.

Conflict of interest: the authors declare no potential conflict of interest.

Funding: none.

Received for publication: 22 March 2018

Revision received: 16 January 2019.

Accepted for publication: 17 January 2019.

This work is licensed under a Creative Commons Attribution-NonCommercial 4.0 International License (CC BY-NC 4.0).

(C) Copyright J. Uddin et al., 2019

Licensee PAGEPress, Italy

Italian Journal of Food Safety 2019; 8:6720

doi:10.4081/ijfs.2019.6720

2015 carried out an investigation on preprocessed raw chicken meat from different supershops of Dhaka city, Bangladesh where they identified Shigella, Salmonella in the chicken meat (Alam et al., 2015). Still, there are relatively few reports on food-borne microorganisms in chicken meat from the major supershops of Dhaka city. Therefore, this study was focused to determine the bacterial contamination in dressed poultry meat sold by main supershops in Bangladesh.

\section{Materials and Methods}

\section{Sample collection and transportation}

Dressed chicken samples (Gallus gallus) were collected from five renowned super shops including $\mathrm{S}_{1}, \mathrm{~S}_{2}, \mathrm{M}_{1}, \mathrm{M}_{2}$, A of Dhaka, Bangladesh. The super shops were visited two times during the investigation. All the chicken samples were kept at $-20^{\circ} \mathrm{C}$ for a maximum of 7 days in the shop. Five chicken samples were taken, two of which were from the supershop $S_{1}, S_{2}$ and other two were from $\mathrm{M}_{1}, \mathrm{M}_{2}$ respectively. The other sample was taken from supershop A. The different kind of samples (skin, wings, 
leg and chest) were collected from all the chicken carcasses to determine the presence of three enteric pathogens such as Escherichia coli, Salmonella spp., and Shigella spp. Samplings were carried out aseptically during the collection of chicken sample. After collection, all the samples were transported to the laboratory immediately in an insulated box with ice to avoid any change in the quality of sample due to microbial action.

\section{Sample processing}

Skin, wings, leg and chest portion of dressed chicken was cut using separate knife and gloves. Skin parts were basically selected from the muscle surfaces. Chopping board cover, gloves were changed every time and knife was cleaned with $70 \%$ ethanol and burnt in order to prevent transferring of bacteria from one part to another. Then, 1 gram of each sample was weighed and transferred into a sterile falcon tube containing $9 \mathrm{~mL}$ of sterile normal saline $(0.85 \% \mathrm{NaCl})$. The contents of falcon tube were mixed properly using a vortex machine and serial dilution was performed up to $10^{-3}$ dilution.

\section{Enumeration of Escherichia coli, Salmonella spp. and Shigella spp.}

An aliquot of $50 \mu \mathrm{L}$ was spread on Eosin Methylene Blue (EMB) agar for the enumeration of $E$. coli and SalmonellaShigella (SS) agar for the enumeration of Salmonella spp., Shigella spp. respectively. All plates were incubated at $37^{\circ} \mathrm{C}$ for 24 to 48 hours. The colonies of E. coli, Salmonella spp. and Shigella spp. appeared to be green metallic sheen, black centered and transparent in the medium after incubation. Following incubation, number of colony was counted in $\mathrm{CFU} / \mathrm{g}$ units.

\section{Molecular characterization of $\boldsymbol{E}$. coli, Salmonella spp. and Shigella spp.}

\section{Isolation of pure bacterial colonies}

To isolate pure colonies of bacteria, green metallic sheen colonies on EMB agar, black centered and transparent colony on SS agar were sub-cultured onto nutrient agar (NA) agar plates. The plates were incubated at $37^{\circ} \mathrm{C}$ for $24 \mathrm{~h}$.

\section{DNA extraction}

After isolation of pure colony from each bacterium, DNA was extracted by heat shock method to ensure the presence of E.coli, Salmonella spp. and Shigella spp. by Polymerase Chain Reaction (PCR). A loop full (2 or 3 numbers of colonies) of overnight bacterial culture was suspended in a $1.5 \mathrm{~mL}$ Eppendorf tube containing 500 $\mu \mathrm{L}$ of sterile distilled water and mixed thoroughly by using vortex machine. Then it was boiled for $100^{\circ} \mathrm{C}$ for 10 minutes and immediately cooled at $0^{\circ} \mathrm{C}$ for 10 minutes. The tube was then placed in a centrifuge (Eppendorf, Germany) and centrifuged for $13000 \mathrm{rpm}$ (Rotation per minutes) for 8 minutes. The supernatant was withdrawn ( $70 \mu \mathrm{L}$ ) from the tube and used as the DNA template for PCR amplification of the specific bacteria. The template DNA was then stored at $-20^{\circ} \mathrm{C}$ until analysis.

\section{Polymerase chain reaction assay}

Monoplex Polymerase chain reaction (PCR) was used for the identification of $E$. coli, Salmonella spp. and Shigella spp. present in the meat samples. Three set of primers (LT-F and LT-R targeting LT virulence gene of E. coli; Sal-201f and sal-597r targeting 16S rRNA gene of Salmonella spp.; IpaH-F and IpaH-R targeting IpaH virulence gene of Shigella spp.) were used for the detection of these specified bacteria.

\section{Molecular detection of enterotoxi- genic $E$. coli}

The PCR assay for detection of Enterotoxigenic E. coli was carried out in $25 \mu \mathrm{L}$ reaction mixture using two primers (Nguyen et al., 2009) LT-F (5'-TAGAGACCGGTATTACAGAAATCTGA-3'), LT-R (3'-TCATCCCGAATTCTGTTATATATGTC-5'). The reaction mixture consisted of $1 \mu \mathrm{L}$ each of reverse and forward primer, $12.5 \mu \mathrm{L}$ of master mixture and $6.5 \mu \mathrm{L}$ of distilled water and $4 \mu \mathrm{L}$ of template DNA. The PCR reaction was performed with a total of 32 cycles: $94^{\circ} \mathrm{C}$ for $3 \mathrm{~min}$, followed by $94^{\circ} \mathrm{C}$ for $30 \mathrm{sec}, 55^{\circ} \mathrm{C}$ for $60 \mathrm{sec}, 72^{\circ} \mathrm{C}$ for $60 \mathrm{sec}$ and then finally extended at $72^{\circ} \mathrm{C}$ for $10 \mathrm{~min}$ and held at $4^{\circ} \mathrm{C}$. The PCR products were electrophoresed in a $1.5 \%$ agarose gel, followed by staining with ethidium bromide for 30 minutes. It was then visualized under ultraviolet (UV) light. The bands were recorded by photography.

\section{PCR amplification of 16s r-RNA gene of Salmonella spp.}

The 16s r-RNA gene of Salmonella spp. was detected using Sal-201f (5'-CGGGCCTCTTGCCATCAGGTG-3') and sal-597r (3'-CACATCCGACTTGACAGACCG-5') primers (Amit-Romach et al., 2004). For PCR amplification of Salmonella spp., $4 \mu \mathrm{L}$ of DNA extract was added to $21 \mu \mathrm{L}$ of PCR mixture containing $12.5 \mu \mathrm{L}$ of nuclease-free water, $1 \mu \mathrm{L}$ of each primer, $6.5 \mu \mathrm{L}$ of distilled water. After initial denaturation at $94^{\circ} \mathrm{C}$ for $3 \mathrm{~min}$, the reaction mixture was run through 35 cycles of denaturation at $94^{\circ} \mathrm{C}$ for $30 \mathrm{~s}, 60^{\circ} \mathrm{C}$ for $1 \mathrm{~min}$ and $68^{\circ} \mathrm{C}$ for $2 \mathrm{~min}$, and finally 1 cycle of $68^{\circ} \mathrm{C}$ for $7 \mathrm{~min}$. Products of PCR were visualized by agarose gel (2\%) electrophoresis containing ethidium bromide.

\section{Detection of IpaH virulence gene of} Shigella spp. by PCR

The PCR reaction for amplification of IpaH gene of Shigella spp. was carried out in standard $25 \mu \mathrm{L}$ reaction in $0.2 \mathrm{~mL}$ PCR tube (Eppendorf, Germany) using IpaH $\mathrm{F}$ (5'-GCTGGAAAAACTCAGTGCCT-3') and IpaH R (5'-CCAGTCCGTAAATTCATTCT-3') primers (Sharma et al., 2010). $4 \mu \mathrm{L}$ of DNA was used as a template and $12.5 \mu \mathrm{L}$ of nuclease-free water, 1 $\mu \mathrm{L}$ of each primer, $6.5 \mu \mathrm{L}$ of distilled water was added in the reaction mixture. The mixture containing PCR tubes were placed in thermal cycler (Eppendorf, Germany). The cycling conditions for amplification included $94^{\circ} \mathrm{C}$ for $1 \mathrm{~min}$ (initial denaturation), $94^{\circ} \mathrm{C}$ for $2 \mathrm{~min}$ (denaturation), annealing at $55^{\circ} \mathrm{C}$ for $2 \mathrm{~min}, 72^{\circ} \mathrm{C}$ for $3 \mathrm{~min}$ (polymerization) followed by $72^{\circ} \mathrm{C}$ for $10 \mathrm{~min}$. The amplicon was visualized by electrophoresis of the product in $1.5 \%$ agarose gel stained with ethidium bromide.

\section{Results}

Three genera of bacteria were isolated from all of the chicken meat samples. The isolates were presumptively identified as $E$. coli, Salmonella spp., and Shigella spp. by conventional culture method whereas only E. coli was confirmed by polymerase chain reaction. These enteropathogens from various organs of dressing chickens were also enumerated. The load of E. coli, Shigella spp. were higher than that of Salmonella spp. in dressed chickens.

\section{$E$. coli count in dressed chickens}

The load of E. coli in different parts of dressed chickens from different supermarket shops ranged between $0 \log \mathrm{CFU} / \mathrm{g}$ to $3.38 \log \mathrm{CFU} / \mathrm{g}$ respectively. The highest number of $E$. coli was found in $\mathrm{M}_{2}$ (3.05 log $\mathrm{CFU} / \mathrm{g}$ in average of chest, wings, leg, skin) followed by $\mathrm{M}_{1}$ (3.04 $\mathrm{log} \mathrm{CFU} / \mathrm{g}$ in average), $\mathrm{S}_{1}$ (2.46 log CFU/g in average), A (0.60 log CFU/g in average). No count of $E$. coli was recorded in $\mathrm{S}_{2}$ sample. The highest count of $E$. coli was in wings (3.38 log $\mathrm{CFU} / \mathrm{g}$ ) rather than leg (3.37 log CFU/g), chest (3.31 log CFU/g) or skin (0 log $\mathrm{CFU} / \mathrm{g}$ ) for the chicken sample collected from $\mathrm{S}_{1}$. E. coli was never detected from wings, leg, chest and skin samples of second chicken collected from $\mathrm{S}_{2}$. The count of E. coli was also higher, mostly in the part of the chest (3.36 log, $3.31 \log \mathrm{CFU} / \mathrm{g}$ ) rather than leg (3.17 log, $3.06 \log \mathrm{CFU} / \mathrm{g})$, skin (3 $\log , 2.92 \mathrm{log} \mathrm{CFU} / \mathrm{g}$ ) or wings (2.69 $\mathrm{log}$, $2.87 \log \mathrm{CFU} / \mathrm{g}$ ) for the dressed chicken of $\mathrm{M}\left(\mathrm{M}_{2} \& \mathrm{M}_{1}\right)$. Mean levels of $E$. coli were 
very low (1.36 log CFU/g in skin, $1.07 \mathrm{log}$ $\mathrm{CFU} / \mathrm{g}$ in wings, 0 log CFU/g in leg and in skin respectively) in the chicken collected from A (Figure 1).

\section{Salmonella spp. in dressed chickens}

Salmonella spp. load in dressed chickens of five supershops was relatively lower than $E$. coli found in chicken samples of these supershops. The number of Salmonella spp. was higher in wings part (1.82 $\log$ CFU/g) of chicken samples of $\mathrm{S}_{1}$ than other parts such as chest $(1.54 \log$ $\mathrm{CFU} / \mathrm{g})$, leg and skin (0 log CFU/g). The skin parts of chicken samples collected from $\mathrm{S}_{2}$ was also found contaminated with high number of Salmonella spp. (3.36 log $\mathrm{CFU} / \mathrm{g}$ ) compared to wings (1.69 log $\mathrm{CFU} / \mathrm{g}$ ), legs (1.67 log CFU/g) and chest parts $(0.47 \log \mathrm{CFU} / \mathrm{g})$. Again, the highest count of Salmonella spp. was recorded in chest of chicken samples from $\mathrm{M}_{2}$ and $\mathrm{M}_{1}$ supershops. The load of Salmonella spp. was $2.67 \log \mathrm{CFU} / \mathrm{g}$ in chest followed by $2.07 \log \mathrm{CFU} / \mathrm{g}, 1.47 \mathrm{log} \mathrm{CFU} / \mathrm{g}$ and $1.3 \mathrm{log}$ $\mathrm{CFU} / \mathrm{g}$ in skin, wings and leg respectively in chicken sample of $\mathrm{M}_{2}$. Similarly, the highest count of Salmonella was found in chest (2.64 log CFU/g) compared to wings (1.84 CFU/g), skin (1.3 CFU/g) and leg (1.07 CFU/g) of chicken collected from $\mathrm{M}_{1}$. In case of the chicken which was collected from A, Salmonella spp. was never detected from chest, leg, wings and skin samples (Figure 2).

\section{Shigella spp. count in dressed chickens}

The chicken samples from five supershops were also contaminated with high number of Shigella spp. The count of Shigella was higher in wings part (3.42 log $\mathrm{CFU} / \mathrm{g})$ than any other parts such as chest (3.29 log CFU/g), skin (3.25 CFU/g) and leg (3.02 CFU/g) in dressed chicken of $\mathrm{S}_{1}$. Shigella spp. was also found in high numbers in skin and leg parts (3.47 log CFU/g, $3.47 \log \mathrm{CFU} / \mathrm{g}$ ) than wings, chest (2.95 log $\mathrm{CFU} / \mathrm{g}, 2.47 \mathrm{log} \mathrm{CFU} / \mathrm{g}$ ) parts of chicken from $\mathrm{S}_{2}$.

Again, the highest count of Shigella spp. was recorded in skin parts of chicken collected from $\mathrm{M}_{1}$ and $\mathrm{M}_{2}$ (3.45 log CFU/g, $3.39 \log$ CFU/g). The load of Shigella spp. in wings, leg and chest parts of chicken from $\mathrm{M}_{1}$ was 3.25, 3.02 and $2.97 \log \mathrm{CFU} / \mathrm{g}$ respectively. The leg, wings and chest of chicken sample of $\mathrm{M}_{2}$ was also recorded with high number of Shigella spp. (3.3 log $\mathrm{CFU} / \mathrm{g}, 3.17 \log \mathrm{CFU} / \mathrm{g}, 3 \log \mathrm{CFU} / \mathrm{g}$ ). Shigella spp. was never detected in skin and leg of chicken sample from A except in wings (1.23 log CFU/g), chest (1 $\log$ $\mathrm{CFU} / \mathrm{g}$ ) part (Figure 3).

\section{Confirmation of enteropathogens as virulent by PCR assay}

Three enteropathogens (E. coli, Salmonella spp., Shigella spp.) presumptively isolated from chicken samples by conventional culture methods were further tested for their confirmation as virulent enteropathogens by PCR assay. Only $E$ coli isolates were confirmed as enterotoxigenic
$E$ coli. The enterotoxigenic $E$ coli was identified on the basis of the 282 bp PCR product corresponding to the sequence of LT virulent gene on $1.5 \%$ agarose gel whereas other isolates were not confirmed as virulent Salmonella spp., Shigella spp. When they were analyzed with virulent $16 \mathrm{~S}$ rRNA (Salmonella spp.) and IpaH gene (Shigella spp.) specific PCR amplification, they did

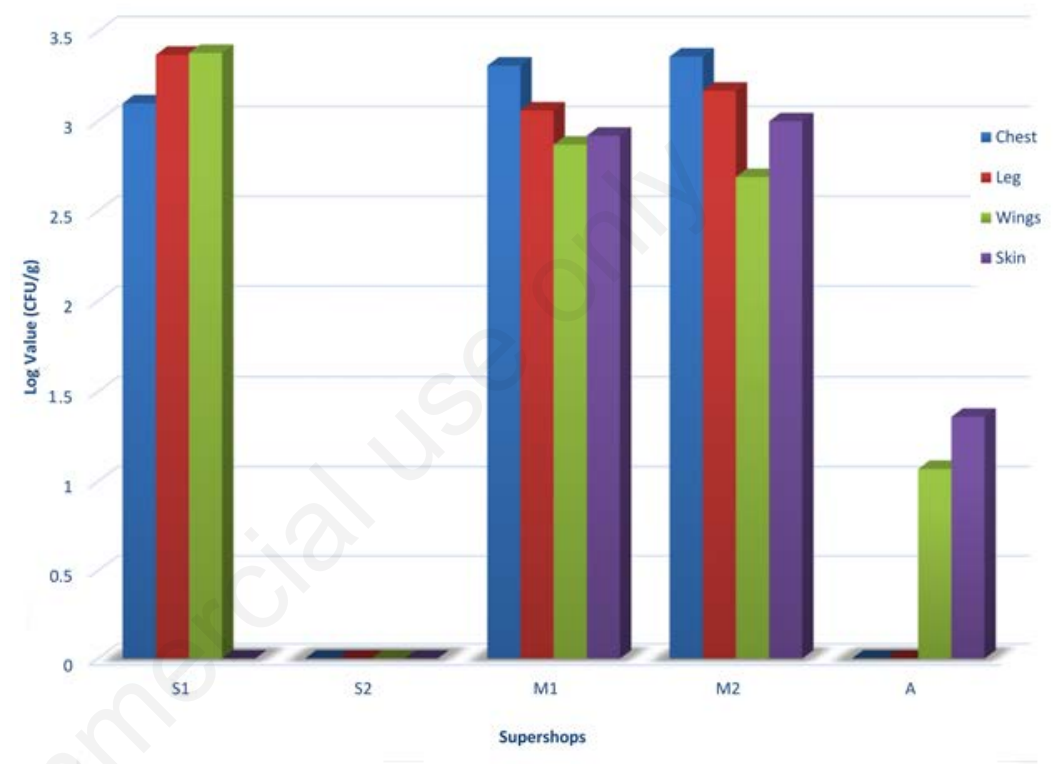

Figure 1. Enumeration of $E$. coli in various parts of dressed chicken samples.

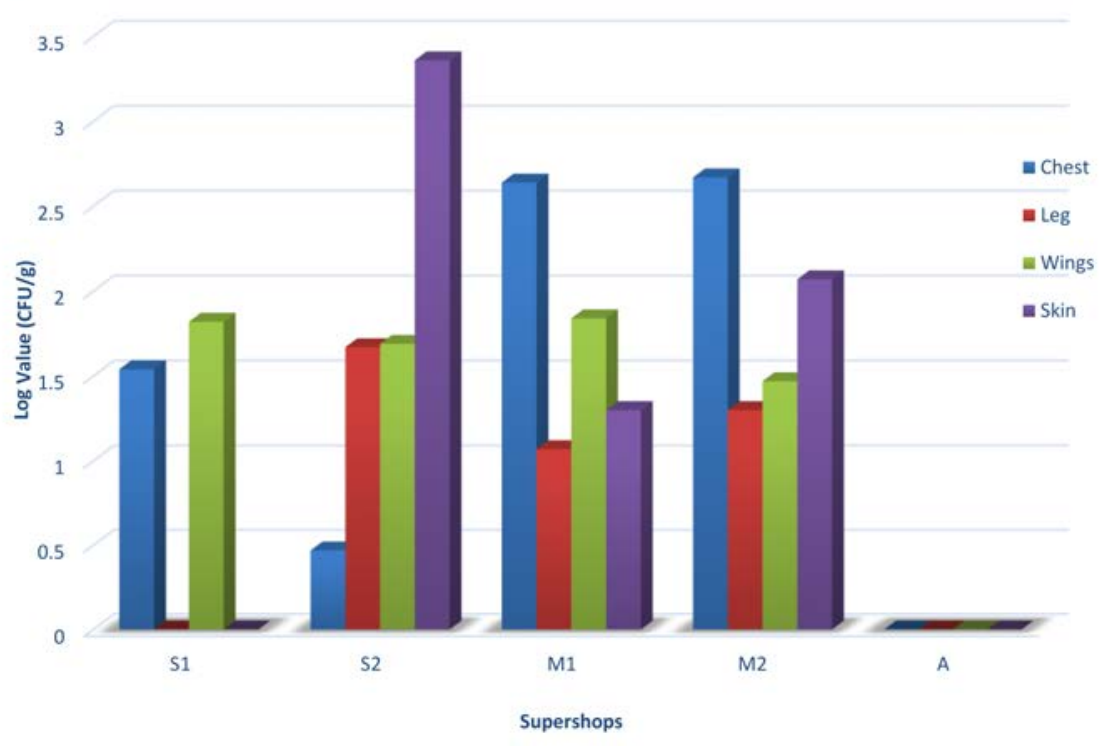

Figure 2. Salmonella spp. count in different parts of dressed chicken. 
not show any virulent $16 \mathrm{~S}$ rRNA and IpaH gene (Table 1).

\section{Discussion}

Poultry meat is found with E. coli, Salmonella spp. and Staphylococcus spp. (Malmuthuge et al., 2012; Sudershan et al., 2012; Voidarou et al., 2011; Torok et al., 2011; Petrović et al., 2011; Awad-Alla et al., 2010; Ahmed et al., 2009). Several studies had been carried out in Bangladesh by Akond et al, 2009 and Islam et al., 2014 where they reported the presence of E. coli, Salmonella spp., Staphylococcus aureus in poultry meat and chicken rinse samples (Akond et al, 2009; Islam et al., 2014). In the present study, several microorganisms like E. coli, Salmonella spp., Shigella spp. were found from various parts of chicken samples collected from five supershops of Dhaka city, Bangladesh. These various parts of chicken samples are often bought separately by the consumers. The pathogenic bacteria usually absent in the muscle tissue and body fluids of healthy living animals. But, the pathogens can be introduced into the meat during slaughtering or at the time of processing where the source of these pathogens may be endogenous from the gastrointestinal tract or from surrounding environment in farm and/ or slaughterhouse (Samaha et al., 2012).

During the present investigation, pathogens like E coli, Salmonella spp., Shigella spp. were found from dressed chicken samples of five supershops where the count of E. coli and Shigella spp. were higher than that of Salmonella spp. in dressed chickens. Two study by Frazier and Westhoff (1983) and Hashim (2003) showed that $E$. coli is present in examined chicken meat and chicken meat products due to improper handling or unhygienic conditions (Frazier et al., 1983; Hashim, 2003).

Shah et al., 2012 reported that the high prevalence of Salmonella in chicken meat may be due to cross-contamination from intestines during processing and cutting or from cages, floor and workers during retailing or marketing. They also concluded that water used for washing of carcasses may be responsible for this and the meat could be contaminated with Salmonella from feces or from the butcher's hands during washing (Shah et al., 2012). Another study by Cason et al., 1999 and James et al., 1992 revealed that contamination of poultry by Salmonella may be occurred during poultry meat production and processing. The contamination may occur during transportation to the poultry-processing plant or during the steps involved in slaughtering, scalding, defeathering, plucking and chilling of the poultry carcasses, (Cason et al., 1999; James et al., 1992). The Shigella spp. in the dressed chicken may be attributed to the unhygienic practices of workers while handling and processing of meat.

The high incidence of contamination of poultry meat with enteric pathogens appears to have two major causes. The causes may be the practice of intensive rearing that encourages rapid transmission of pathogens through flocks and the very high rates of throughput at large processing plants which enhance the spread of microorganisms among carcasses during processing (Robinson, 1985).

The dressed chicken samples were contaminated with E. coli, Salmonella spp. and Shigella spp., but when they were analyzed by virulence gene specific PCR, Only $E$. coli were found as enterotoxigenic. The other strain Salmonella spp. and Shigella spp. were not confirmed as pathogenic. It is well understood that that the pathogenic form of $E$. coli is a public health threat by which bloody diarrhea, hemorrhagic colitis and a life-threatening hemolytic-uremic syndrome (HUS) can be occurred (Magwedere et al., 2013; Parma et al., 2012; Liu et al., 2011; Käppeli et al., 2011; Fratamico et al., 2011. When this E. coli is enterotoxigenic, the infection caused by the entrotoxigenic $E$. coli due to ingestion of contaminated food or water produces

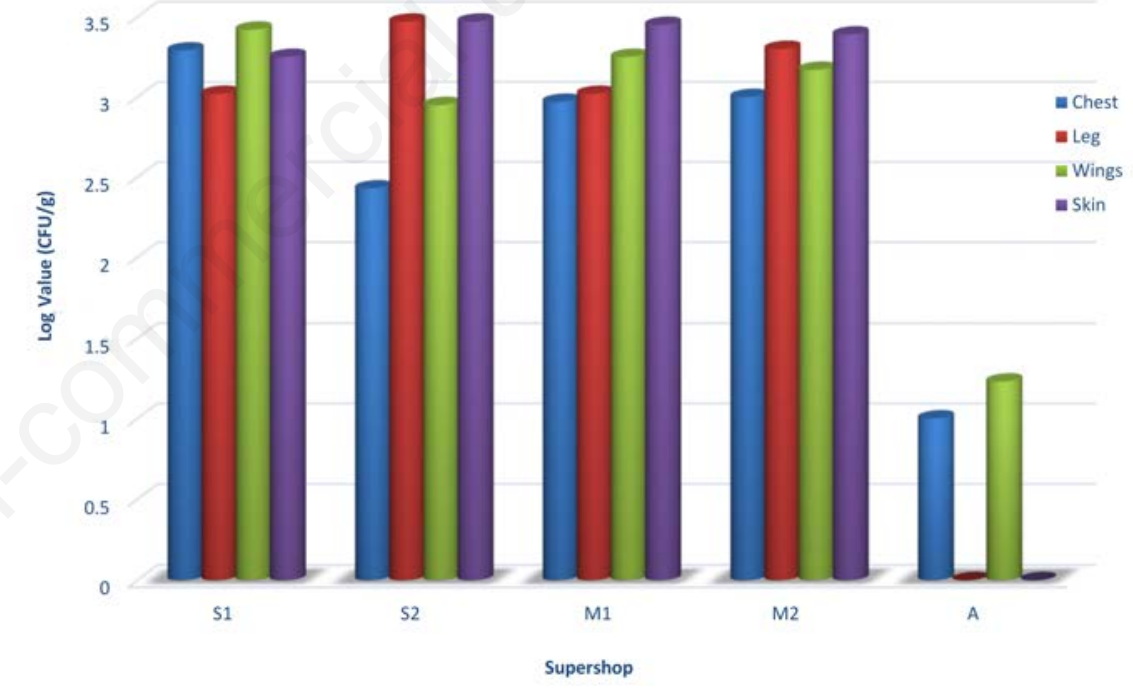

Figure 3. Enumeration of Shigella spp. in chest, leg, wings and skin parts of dressed chicken.

Table 1. Molecular confirmation of enteropathogens isolated from different parts of chicken samples by polymerase chain reaction assay.

\begin{tabular}{|c|c|c|c|c|}
\hline $\begin{array}{l}\text { Different parts of } \\
\text { chicken samples }\end{array}$ & Name of supershops & $\begin{array}{c}E . \text { coli (ETEC) } \\
\text { LT gene }\end{array}$ & $\begin{array}{l}\text { Bacterial genera } \\
\text { Salmonella spp. } \\
\text { 16s-rRNA gene }\end{array}$ & $\begin{array}{l}\text { Shigella spp. } \\
\text { IpaH gene }\end{array}$ \\
\hline Chest & $S_{1}-S_{2}-M_{1}-M_{2}-A$ & + & - & - \\
\hline Leg & $S_{1}-S_{2}-M_{1}-M_{2}-A$ & + & - & - \\
\hline Wings & $S_{1}-S_{2}-M_{1}-M_{2}-A$ & + & - & - \\
\hline Skin & $S_{1}-S_{2}-M_{1}-M_{2}-A$ & + & - & - \\
\hline
\end{tabular}


abdominal cramps, low-grade, fever, watery diarrhea and nausea (Nweze, 2009).

The increasing prevalence of pathogens in foods owing to poor hygienic practices is increasing the risk of food borne disease for consumers (Sivapalasingam et al., 2004). The present study demonstrates that dressed chicken meat is contaminated with enterotoxigenic E. coli (ETEC) and this may be a potential hazard to the consumers. The government should adopt regulation to enforce the application of the handling, marketing and storage of poultry meat as a means to identify and control this potential hazard in poultry slaughter houses. These measures may be helpful to prevent ETEC infection in dressed chicken meat sold by main supershops in Bangladesh.

\section{Conclusions}

The result demonstrated that dressed chicken samples possess virulent LT gene of $E$. coli could be a potential hazard to the consumers. Further exploration of other virulent strains like enteropathogenic $E$ coli (EPEC), enteroinvasive E. coli (EIEC) and enterohemorrhagic E. coli (EHEC) is needed to figure out the particular situation of $E$. coli contaminated poultry meat at different supershops of Dhaka as well as other cities in Bangladesh.

\section{References}

Ahmed AM, Shimabukuro H, Shimamoto T, 2009. Isolation and Molecular Characterization of MultidrugResistant Strains of Escherichia coli and Salmonella from Retail Chicken Meat in Japan. J Food Sci 74:M405-10.

Akond MA, Alam S, Hasan SMR, Shirin M, 2009. Antibiotic resistance of Escherichia coli isolated from poultry and poultry environment of Bangladesh. Internet J Food Safety 11:19-23.

Akond MA, Shirin M, Alam S, Hassan SMR, Rahman MM, Hoq M, 2013. Frequency of drug resistant Salmonella spp.. isolated from poultry samples in Bangladesh. Stam J Microbiol 2:15-9.

Alam ST, Howard M, Fatema K, Haque K, Formuzul M, 2015. Antibiogram of preprocessed raw chicken meat from different supershops of Dhaka city, Bangladesh. Daffodil Int Univ J AllHealth Sci 2:45-52.

Amit-Romach E, Sklan D, Uni Z, 2004. Microflora ecology of the chicken intestine using $16 \mathrm{~S}$ ribosomal DNA primers.
Poult Sci 83:1093-8.

Awad-Alla ME, Abdien H, Dessouki AA, 2010. Prevalence of bacteria and parasites in White Ibis in Egypt. Vet Ital 46:277-86.

Bangladesh Bureau of Statistics (BBS), 2008.Report on the Bangladesh Livestock Survey 2008-09. Government of Bangladesh.

Cason JA, Buhr RJ, Dickens JA, Musgrove MT, Stern NJ, 1999. Carcass microbiological quality jejuni following intermittent scalding and defeathering. J App Poult Res 8:368-73.

FAO, 2013.Food and Agricultural Organization of the United Nation report on Poultry and Human Health. Publication on Veterinary Public Health.

Fratamico PM, Bagi LK, Cray WC Jr, Narang N, Yan X, Medina M, Liu Y, 2011. Detection by multiplex real-time polymerase chain reaction assays and isolation of Shiga toxin producing Escherichia coli serogroups O26, O45, O103, O111, O121, and O145 in ground beef. Foodborne Pathog Dis 8:601-7.

Frazier W, Westhoff D, 1983.Food microbiology 3rd Ed.TATA McGraw-Hill publishing company limited., New Delhi, India..

Hashim ESY, 2003.Aerobic and anaerobic enterotoxigenic bacteria in ready to-eat food. Food and Agricultural Organisation of the United Nations.

Huque Q, 2001. Poultry industry in Bangladesh and strategies for its improvement. In Proceeding of WPSA BB seminar held in 2001, Dhaka.

Islam NN, Akter M, Farzana Z, Kader AJB, Uddin I, Siddiki AMAM Z, Kamaruddin K.M, 2014. Detection of Staphylococcus aureus in frozen chicken rinse through bacteriological and Nuc gene specific PCR methods and their drug resistance patterns in Southern Chittagong, Bangladesh Res J Microbiol 9:251-264.

James WO, Williams WO, Prucha JC, Johnston R, Christensen W, 1992. Profile of selected bacterial counts and Salmonella prevalence on raw poultry in a poultry slaughter establishment. $\mathrm{J}$ Am Vet Med Assoc 200:57-59.

Käppeli U, Hächler H, Giezendanner N, Beutin L, Stephan R, 2011. Human Infections with Non-O157 Shiga Toxin-producing Escherichia coli, Switzerland, 2000-2009. Emerg Infect Dis 17:180-5.

Kapperud G, Rørvik LM, Hasseltvedt V, Høiby EA, Iversen BG, Staveland K, Johnsen G, Leitao J, Herikstad H, Andersson Y, 1995. Outbreak of
Shigella sonnei infection traced to imported iceberg lettuce. J Clin Microbiol 33:609-14.

Levine MM, 1987. Escherichia coli that cause diarrhea: enterotoxigenic, enteropathogenic, enteroinvasive, enterohemorrhagic, and enteroadherent. J Infect Dis $155: 377-89$.

Limawongpranee S, Hayashidani H, Okatani AT, Ono K, Hirota C, Kaneko K, Ogawa M, 1999. Prevalence and persistence of Salmonella in broiler chicken flocks. J Vet Med Sci 61:255-9.

Liu F, Huang J, Sadler JE, 2011.Shiga toxin (Stx) 1B and Stx2B induce von Willebrand factor secretion from human umbilical vein endothelial cells through different signaling pathways. Blood 118:3392-8.

Magwedere K, Dang HA, Mills EW, Cutter CN, Roberts EL, DeBroy C, 2013. Incidence of Shiga toxin-producing Escherichia coli strains in beef, pork, chicken, deer, boar, bison, and rabbit retail meat. J Vet Diagn Invest 25:2548.

Malmuthuge N, Li M, Chen Y, Fries P, Griebel PJ, Baurhoo B, Zhao X, Guan LL, 2012. Distinct commensal bacteria associated with ingesta and mucosal epithelium in the gastrointestinal tracts of calves and chickens. FEMS Microbiol Ecol 79:337-47.

Mokhtari W, Nsaibia S, Majouri D, Ben Hassen A, Gharbi A, Aouni M, 2012. Detection and characterization of Shigella species isolated from food and human stool samples in Nabeul, Tunisia, by molecular methods and culture techniques. J Appl Microbiol 113:209-22.

Nguyen TL, Truong HT, Nguyen VG, 2009. Determining virulence factors of Escherichia strains meats isolated from diarrhea piglets by using PCR method. J Sci Scotland Dev 7:187:191.

Nweze E, 2009. Virulence Properties of diarrheagenic E. coli and etiology of diarrhea in infants, young children and other age groups in Southeast, Nigeria. American-Eurasian J Sci Res 4:173-9.

Parma YR, Chacana PA, Lucchesi PMA, Rogé AG, Krüger A, Parma AE, Fernández-Miyakawa ME, 2012. Detection of Shiga toxin-producing Escherichia coli by sandwich enzymelinked immunosorbent assay using chicken egg yolk IgY antibodies. Front Cell Infect Microbiol 2:84

Petrović J, Stojanov I, Milanov D, Kapetanov M, 2011. Antimicrobial resistance of thermotolerant Campylobacter spp. as a food safety issue. Biotech Anim Husbandry 
27:1321-8.

Robinson RK, 1985. Microbiology of Frozen Foods. Elsevier Applied Science Publishing Ltd, England.

Rahman M, 2003. Growth of poultry industry in Bangladesh poverty alleviation and employment opportunity. in Proceedings of 3rd International Poultry Show and Seminar, Organized by World's Poultry Science AssociationBangladesh Branch.

Samaha I, Ibrahim H, Hamada M, 2012. Isolation of some enteropathogens from retailed poultry meat in Alexandria Province. Alexandria J Vet Sci 37:1722.

Shah AH, Korejo NA, 2012. Resistance profile of Salmonella serovars isolated from chicken meat. J Vet Anim Sci

\section{2:40-6.}

Sharma A, Singh SK, Bajpai D, 2010. Phenotypic and genotypic characterization of Shigella spp. with reference to its virulence genes and antibiogram analysis from river Narmada. Microbiol Res 165:33-42.

Sivapalasingam S, Friedman CR, Cohen L, Tauxe RV, 2004. Fresh produce: a growing cause of outbreaks of foodborne illness in the United States, 1973 through 1997. J Food Prot 67:2342-53.

Sudershan RV, Kumar NR, Kashinath L, Bhaskar V, Polasa K, 2012. Microbiological hazard identification and exposure assessment of poultry products sold in various localities of Hyderabad, India. Sci World J 736040.

Torok VA, Hughes RJ, Mikkelsen LL,
Perez-Maldonado R, Balding K, MacAlpine R, J. Percy N, Ophel-Keller $\mathrm{K}, 2011$. Identification and characterization of potential performance-related gut microbiotas in broiler chickens across various feeding trials. Appl Environ Microbiol 77:5868-78.

Voidarou C, Vassos D, Rozos G, Alexopoulos A, Plessas S, Tsinas A, Skoufou M, Stavropoulou E, Bezirtzoglou E, 2011. Microbial challenges of poultry meat production. Anaerobe 17:341-3.

Wu FM, Doyle MP, Beuchat LR, Wells JG, Mintz ED, Swaminathan B, 2000. Fate of Shigella sonnei on parsley and methods of disinfection. J Food Prot 63:56872. 